\title{
A Study on Effect of Organic Manures on Green Gram [Phaseolus radiate L.]
}

\author{
Alka Pandey ${ }^{*}$ and Pawan Sirothia \\ Department of Soil Science, Mahatma Gandhi Chitrakoot Gramodaya Vishwavidyalaya, \\ Chitrakoot, Satna (M.P.), India \\ *Corresponding author
}

\section{A B S T R A C T}

\section{Keywords \\ Mungbean, FYM, Vermicompost, Pod initiation, Pod initiation, Seed yield, Yield attributes.}

\section{Article Info}

Accepted: 10 July 2020 Available Online: 10 August 2020
The experiment was conducted at the Rajaula Agricultural Research farm of the Faculty of Agricultural Sciences, Mahatma Gandhi Chitrakoot Gramodaya Vishwavidyalaya, Chitrakoot - Satna (Madhya Pradesh) during kharif, 2018. The objective was to find out the best treatment comprising of FYM and vermicompost on growth and yield of green gram. In this investigation nine treatments were tested in randomized block design with three replications. Randomly five plants were selected to record the observations on different eight characters. Significantly maximum seed yield $(7.21 \mathrm{q} / \mathrm{ha})$ was recorded under $\mathrm{T}_{8}:\left(\mathrm{FYM}_{2} \mathrm{~V}_{2}\right)$ followed by $6.43 \mathrm{q} / \mathrm{ha} \mathrm{T}_{7}$ $\left(\mathrm{FYM}_{2} \mathrm{~V}_{1}\right)$ and over control.

\section{Introduction}

Mungbean are in the legume family of plants and are closely related to adzuki and cowpea (in the same genus but different species).The requirement of pulses is expected to rise farther mainly due to increasing population and preference for pulses as the cheapest source of dietary protein. It contains $24.5 \%$ protein and carbohydrate, it also contains $75 \mathrm{mg}$ calcium, $8.5 \mathrm{mg}$ iron and $49 \mathrm{mg} \mathrm{R}-$ carotene per $100 \mathrm{~g}$ of pulses. Productivity of crop is below the average owing to several inert soils related constrains such as low organic matter and poor soil fertility hence it required since efforts to enhance productivity. The climatic changes and global warming deleterious effects on crop in terms of period of and yield mungbean is the only crop which can be grown two crops in year different season due to variation in temperature and photoperiod and humidity etc. It matures in 55 to 70 days depending upon cultivators and climate. Farm yard manure is the most important organic source of nutrients and organic matter addition in India much of the effects of FYM can be increased by the addition of phosphate fertilizers (khali and 
jan2002). Farm yard manure and vermi compost are the sources of primary secondary and micro nutrients to the plant growth. Vermicompost, with high water-holding capacity and proper supply of micro and macro nutrients (Edwrds and burrows, 1988 Atiyeh et al., 2002 Arancon et al., 2004), One of the agrotechnical events permitted in biological production is the use of products obtained as a result of composting of organic waste with the help of various types of earthworms. (Clive et al., 2006, GutiérrezMiceli et al., 2007, Singh et al., 2008).

\section{Materials and Methods}

The present investigation was conducted at Chitrakoot, Satna (M. P.) during the Kharif, 2018-19. The objective was to find out the best treatment comprising of FYM and vermicompost on growth and yield of green gram, for this region. In this investigation nine treatments viz. $\mathrm{T}_{0} \quad\left(\mathrm{FYM}_{0} \mathrm{~V}_{0}\right), \mathrm{T}_{1}$ $\left(\mathrm{FYM}_{0} \mathrm{~V}_{1}\right), \mathrm{T}_{2}\left(\mathrm{FYM}_{0} \mathrm{~V}_{2}\right), \mathrm{T}_{3}\left(\mathrm{FYM}_{1} \mathrm{~V}_{0}\right), \mathrm{T}_{4}$ $\left(\mathrm{FYM}_{1} \mathrm{~V}_{1}\right), \mathrm{T}_{5}\left(\mathrm{FYM}_{1} \mathrm{~V}_{2}\right), \mathrm{T}_{6}\left(\mathrm{FYM}_{2} \mathrm{~V}_{0}\right), \mathrm{T}_{7}$ $\left(\mathrm{FYM}_{2} \mathrm{~V}_{1}\right), \mathrm{T}_{8}\left(\mathrm{FYM}_{2} \mathrm{~V}_{2}\right)$, were tested in randomized block design with three replications. randomly five plants were selected to record the observations on different characters viz., plant height, branches, root length, root nodule, seed plant (gm), 1000 seeds weight, selected plant pod weight, yield $q / h a$. Soil samples were collected separately from each plot of the experimental field to a depth of $0-15 \mathrm{~cm}$ prior to sowing of green gram crop. The soil of experimental site was sandy loam in texture, low in organic carbon, nitrogen and phosphorus and medium in available potassium.

The average rainfall in this area is approximately $60-80 \mathrm{~cm}$, with maximum concentration during the monsoon i.e. July to September, with a few occasional showers during the winter months and found that the integrated fertilizer levels application of FYM
@ $5 \mathrm{t} / \mathrm{ha}+100 \% \mathrm{RDF}+$ seed inoculation of biofertilizers recorded significantly higher Pigeon pea yield (15.74 q/ha). Pigeon pea equivalent yield (18.29 q/ha), Gross returns (43930/ha), Net returns (34650/ha) and B: C ratio (3.72) over other $1 \mathrm{NM}$ practices but it was found to be on par with application of FYM @ $5 \mathrm{t} / \mathrm{ha}+50 \%$ RDF + seed inoculation of biofertilizers (15.38q/ha, $17.83 \mathrm{q} / \mathrm{ha}$, 42847/ha, 34032/ha and B:C ratio 3.85, respectively) Sharma et al., (2012). The gross plot size was $5.0 \mathrm{~m} \times 3.0 \mathrm{~m}$ and net plot size was $4.0 \mathrm{~m} \times 2.10 \mathrm{~m}$. Important observations were recorded at appropriate time and economics was calculated on the basis of prevailing market rates.

\section{Results and Discussion}

The result presented in table revealed that significantly higher plant height $(53.10 \mathrm{~cm}$ and $6.4 \mathrm{~cm})$ was recorded in $\mathrm{T}_{8}\left(\mathrm{FYM}_{2} \mathrm{~V}_{2}\right)$ at 40 DAS and 60 DAS respectively. Significantly maximum number of tertiary branch/plant (4.2 nos) was also recorded in the same treatment $\left(\mathrm{T}_{8}\right)\left(\mathrm{FYM}_{2} \mathrm{~V}_{2}\right)$. Highest seed selected plant (g) (13.03) and selected plant pod weight (34.23) was significantly higher in $\left(\mathrm{T}_{4}\right)\left(\mathrm{FYM}_{1} \mathrm{~V}_{1}\right)$ and highest root length $(14.73 \mathrm{~cm})$ and maximum root noodles (27.67 nos) was significantly higher in $\left(\mathrm{T}_{6}\right)\left(\mathrm{FYM}_{2} \mathrm{~V}_{0}\right)$, which was found to be at par with all treatment expect $\mathrm{T}_{0}, \mathrm{~T}_{3}, \mathrm{~T}_{4}$ in case of root length, while at par with $\mathrm{T}_{0}, \mathrm{~T}_{1}, \mathrm{~T}_{2} \& \mathrm{~T}_{7}$ in case of root noodles. Data further revealed that significantly highest 1000 seed weight (40 gram) and highest yield (7.21 q/ha) was also recorded in the same treatment i.e. $\left(\mathrm{T}_{8}\right)$ $\left(\mathrm{FYM}_{2} \mathrm{~V}_{2}\right)$.

Results revealed that all the growth parameters expect number of branches per plant were significantly increased by vermicompost and FYM levels. plant height (recorded at three stages of crop growth) was maximum at $\mathrm{V}_{2} \mathrm{~F}_{2}$ level. Maximum numbers of branches were recorded at $\mathrm{V}_{2} \mathrm{~F}_{2}$ level. The 
same level gave the maximum number of root length plant where as maximum number of root nodule plant was recorded at $\mathrm{V}_{2} \mathrm{~F}_{2}$, the data were significant in case of all the above parameters. The above study is also conformity with the study of Edwrds and burrows, 1988, Atiyeh et al., 2002 and Arancon et al., 2004, where Vermicompost, with high water-holding capacity and proper supply of micro nutrients has positive effect on biomass production and subsequently enhanced plant height.

Table.1 Effect of different treatments on all parameters during study

\begin{tabular}{|c|c|c|c|c|c|c|c|c|c|c|c|c|c|}
\hline \multirow[b]{2}{*}{ S.NO. } & \multirow[b]{2}{*}{ Treatment } & \multicolumn{3}{|c|}{ plant hight (cm) } & \multicolumn{2}{|c|}{ Branches/plant } & \multirow[b]{2}{*}{ root length } & \multirow[b]{2}{*}{ Root nodule } & \multirow[b]{2}{*}{$\begin{array}{c}\text { Seed } \\
\text { selected } \\
\text { plant (gm) }\end{array}$} & \multirow[b]{2}{*}{$\begin{array}{c}\text { Seed slected per } \\
\text { plot (gm) } 1000 \\
\text { seeds wieght }\end{array}$} & \multirow[b]{2}{*}{$\begin{array}{c}\text { Selected } \\
\text { plant pod } \\
\text { weight }\end{array}$} & \multicolumn{2}{|c|}{ Yield } \\
\hline & & 20 DAS & 40 DAS & 60 DAS & $\begin{array}{c}\text { secondry } \\
\text { branch }\end{array}$ & $\begin{array}{l}\text { Tertiary } \\
\text { branch }\end{array}$ & & & & & & $\begin{array}{l}\text { Grain } \\
\text { Yield }\end{array}$ & $\begin{array}{l}\text { Yield } \\
\text { q\ha }\end{array}$ \\
\hline 1 & T0 & 17.50 & 48.00 & 52.27 & 4.63 & 3.73 & 12.57 & 23.00 & 11.63 & 27.33 & 28.53 & 625.00 & 3.70 \\
\hline 2 & $\mathrm{~T} 1$ & 18.77 & 46.20 & 58.73 & 6.33 & 3.77 & 13.83 & 25.00 & 12.67 & 31.33 & 32.40 & 543.33 & 3.73 \\
\hline 3 & $\mathrm{~T} 2$ & 21.60 & 48.73 & 59.33 & 6.27 & 2.83 & 13.43 & 25.00 & 11.50 & 28.33 & 31.23 & 560.00 & 4.63 \\
\hline 4 & $\mathrm{~T} 3$ & 19.17 & 45.40 & 57.53 & 4.50 & 2.90 & 12.37 & 25.67 & 12.93 & 33.67 & 31.40 & 806.67 & 5.33 \\
\hline 5 & $\mathrm{~T} 4$ & 25.47 & 46.73 & 59.10 & 7.43 & 3.47 & 11.97 & 26.67 & 13.03 & 29.67 & 34.23 & 1166.67 & 6.07 \\
\hline 6 & T5 & 19.67 & 45.43 & 57.53 & 5.97 & 3.40 & 14.60 & 26.67 & 12.77 & 34.67 & 30.17 & 626.67 & 4.40 \\
\hline 7 & T6 & 22.00 & 48.53 & 58.67 & 6.53 & 3.07 & 14.73 & 27.67 & 12.03 & 33.00 & 33.13 & 716.67 & 5.40 \\
\hline 8 & $\mathrm{T7}$ & 21.67 & 49.40 & 60.13 & 6.60 & 3.67 & 13.30 & 25.00 & 11.97 & 36.00 & 31.93 & 626.67 & 6.43 \\
\hline 9 & T8 & 25.13 & 53.10 & 60.47 & 6.70 & 4.20 & 14.13 & 25.67 & 11.80 & 40.00 & 32.43 & 563.33 & 7.21 \\
\hline \multicolumn{2}{|c|}{ Maximum } & 25.47 & 53.10 & 60.47 & 7.43 & 4.20 & 14.73 & 27.67 & 13.03 & 40.00 & 34.23 & 1166.67 & 7.21 \\
\hline \multicolumn{2}{|c|}{ Minimum } & 17.50 & 45.40 & 52.27 & 4.50 & 2.83 & 11.97 & 23.00 & 11.50 & 27.33 & 28.53 & 543.33 & 3.70 \\
\hline \multicolumn{2}{|c|}{ Average } & 21.22 & 47.95 & 58.20 & 6.11 & 3.4 & 13.44 & 25.59 & 12.26 & 32.67 & 31.72 & 692.78 & 5.21 \\
\hline \multicolumn{2}{|c|}{ SEm \pm} & 1.59 & 1.36 & 1.36 & 0.54 & 0.28 & 0.59 & 0.83 & 0.34 & 1.92 & 0.72 & 59.73 & 0.62 \\
\hline \multicolumn{2}{|l|}{$\mathrm{CD}_{5 \%}$} & 4.65 & 3.96 & 3.97 & 1.58 & 0.81 & 1.73 & 2.42 & 0.99 & 5.61 & 2.11 & 174.34 & 1.81 \\
\hline \multicolumn{2}{|l|}{ CV } & 13.00 & 4.90 & 4.04 & 15.31 & 13.89 & 7.64 & 5.61 & 4.80 & 10.18 & 3.96 & 14.93 & 20.64 \\
\hline
\end{tabular}

Fig.1

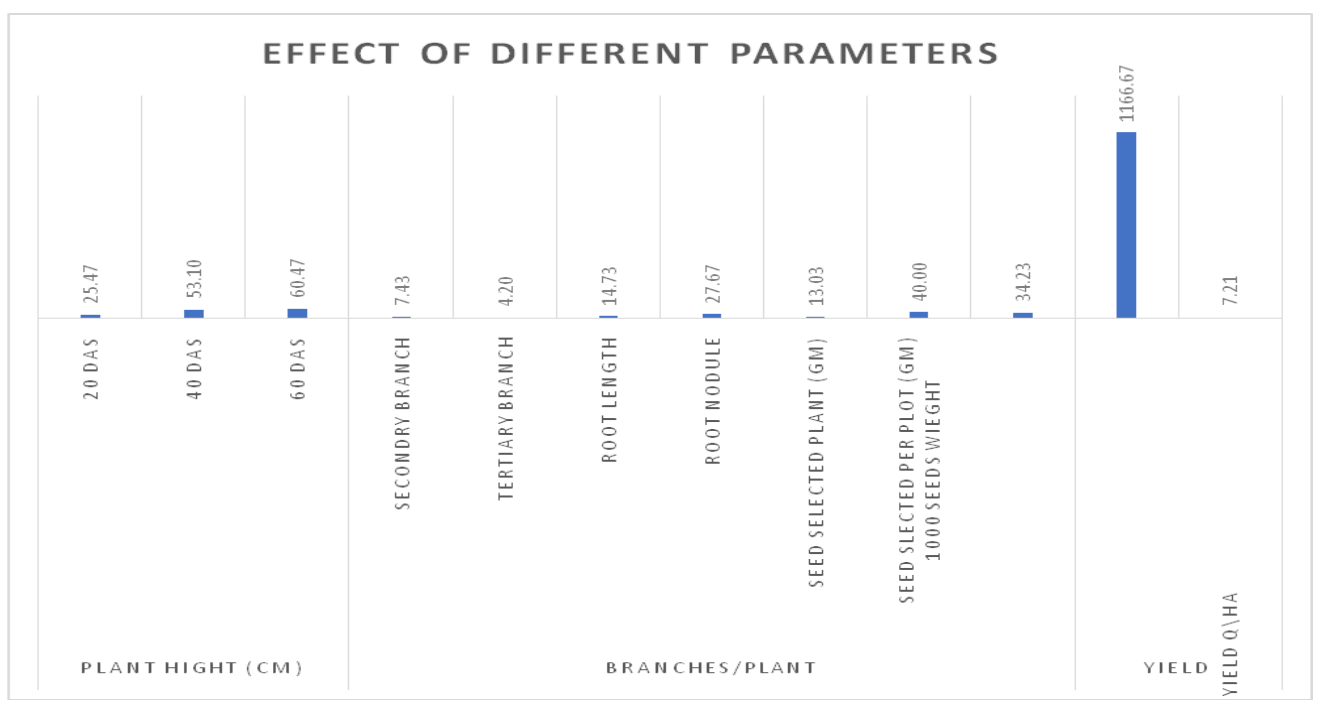


Sharma J. and Agarwal S. (2014), also proved the excellent growth promoter and protector to the crop by using organic fertilizers. It also specified that consistent application of organic fertilizer inputs satisfies the plant demands for growth and yield by enriching the soil. The significant result with regard to number of branches/plants, 1000 grain weight and grain yield were also studied by Verma et al., (2011) in mungbean cv. HUM 12.

\section{References}

Arancon N, Edwards CA, Bierman P, Welch $\mathrm{C}$ and Metzger JD (2004). Influences of vermicompost on field strawberries: Effects on growth and yields. Bioresource Technology, 93:145-153.

Atiyeh RM, Arancon N, Edwards CA and Metzger JD (2002). The influence of earthworm- processed pig manure on the growth and productivity of marigolds. Bioresource Technology, 81(2): 103-108

CliveA., Arancon E., Arancon N., 2006. Mechanisms by which earthworms interact with plant pathogens, plant parasitic nematodes and invertebrate pest arthropods. The 8th Intl. Symp. on Earthworm Ecol., Krakow, Poland, 04-
09 September: 237

Gutierrez-Miceli F., Santiago-Borraz J., Montes MolinaJ., NafateC., AbduArchilaM., OlivaLlaven M., Rincon- Rosales R., Dendooven L., 2007. Vermicompost as a soil supplement to improve growth, yield and fruit quality of tomato (Lycopersicumesculentum).

Bioresource Technol. 98(15): 27812786

Sharma, A., Pandit, S. Rathod., Dhavanraj, D.S. and Chavan, M. (2012). Response of pigeon pea to biofertilizers in pigeon pea based intercropping system under rainfed conditions. Karnataka Agriculture Science 25 (3): 322-325.

Sharma.J and Agarwal.S.,2014. Impact of organic fertilizer on Growth, Yield and Quality of Spinach. Indian Journal of Plant Sciences. Vol. 3 (3) JulySeptember, pp.37-43

Singh R. SharmaR., Kumar S., GuptaR., Patil R., 2008. Vermicompost substitution influences growth, physiological disorders, fruit yield and quality of strawberry (Fragaria $\times$ ananassaDuch.). Bioresource Technol. 99(17): 8507-8511.

\section{How to cite this article:}

Alka Pandey and Pawan Sirothia. 2020. A Study on Effect of Organic Manures on Green Gram [Phaseolus radiate L.]. Int.J.Curr.Microbiol.App.Sci. 9(08): 407-410. doi: https://doi.org/10.20546/ijcmas.2020.908.047 